\title{
Perceptions and Application of Task-Based Language Teaching among Primary School EFL Teachers in Spain
}

\author{
Fatima Taourite*, Raul Ruiz Cecilia \\ Faculty of Educational Sciences, Granada University, Granada, 18011, Spain
}

Received February 6, 2020; Revised March 5, 2020; Accepted March 19, 2020

Copyright $\odot 2020$ by authors, all rights reserved. Authors agree that this article remains permanently open access under the terms of the Creative Commons Attribution License 4.0 International License

\begin{abstract}
The perceptions and understanding of Task-based Language Teaching (TBLT) among Spanish primary English as Foreign Language (EFL) teachers are explored in this research. TBLT is an established active communicative pedagogical approach, but teachers still face problems and refuse using TBLT in their classes. Thus, the following research opened the issue with the Spanish teachers to pave the way for a larger study that aims to discover what teachers think of TBLT and the reasons why teachers refuse or accept to implement TBLT in their teaching. The sample population in the study included 76 EFL teachers with different teaching experiences. This research adopted a quantitative approach using a questionnaire which was carefully modified from Jeon and Hahn's (2006). The results found showed participants have a high level of understanding of TBLT and are aware of its motivational advantage on learners, but they are still afraid of its implication in their classes. Recommendations for a good TBLT training were provided by teachers which may affect teachers' practices and training developers in the Spanish context.
\end{abstract}

Keywords Task-Based Language Teaching, EFL Teachers' Perceptions, Spanish Teaching Context

\section{Introduction}

During the 20th century, the profile of foreign language learning was raised and given greater importance in schools and colleges. ${ }^{1}$ During the same period, a greater focus was placed on the promotion of research, philological studies and training teachers and promoting the learning and teaching of English in Spain. There

1See Escuela central de Idiomas en Madrid, 1911. needed to be a focus on the different teaching methodologies and practices used by teachers at all stages and levels. Since then, Task-based Language Teaching has become a popular approach for teaching and learning English worldwide.

The term Task-Based Language Teaching has been linked to the Indian scholar Prabhu (1987) who was responsible for the 'Bangalore Project,' in which he attempted to implement a new teaching methodology in second language teaching and learning. The project required students to complete a set of tasks in a communicative way and it is regarded as the first step towards using communicative tasks in foreign language learning and has attracted much attention (Ruiz-Cecilia, 2017). Over the subsequent decades, second language acquisition (SLA) researchers, teacher trainers, language teachers, etc... have sought to use TBLT in SLA classes (Ruiz-Cecilia, 2017). Subsequent to Prabhu's work, the term 'task' has been widely defined and scholars have been conflicted in representing and delineating the term. In the eighties, language learning came to be seen as an enlightening process embellishing learners' communication through real life tasks rather than a rigid process (Hişmanoğlu, M., 2011; Hişmanoğlu, S., 2011), a view which saw various task-based approaches flourish (Breen, 1987; Candlin \& Murphy, 1987; Nunan, 1989; Prabhu, 1987, p.47). During the nineties, attention was given to the communicative classroom where task-based lessons were based on pre-task preparation, task performance, and post-task (Skehan, 1996; Willis, 1996).

As the task-based approach gained attention among the foreign language teaching community, the term "task" has been described and interpreted in different ways by many researchers and scholars. In this respect, it is commonly agreed a task is a communicative goal-directed activity with specific objectives (Candlin, 1987; Ellis, 2003; 
Willis, 1996) and is mainly a piece of classroom work in which one side involves learners to participate freely and take part in the classroom practices (Long, 1985, p.89) and the other side engages teachers in the task-based lesson with new and different roles from the roles they used to teach in the traditional classes (Crookes, 1986). In this vein, the task's main focus is on meaning rather than form (Willis, 1996 \& Nunan, 1989) which means students' prime center of attraction is to understand the language message and signification rather than learning the language structure in vacuum (Long, 1985 \& Skehan, 1998). The role of the teacher is not neglected but it is modified and adjusted according to the approach objectives and pedagogy. Martin Bygate's (2001) work, one of the most recent developments in TBLT is that task-based language teaching emphasis is on meaning and developing learners' communicative language ability by giving importance to teachers' companionship in TBLT implementation.

Whilst these multiple definitions exist, they do share common points from which it is possible to conclude the task is a learner-centered pedagogical activity. In this definition the task has a communicative goal which focuses on meaning rather than the language structure. It creates opportunities for learners to take part in communicative tasks and to contribute in real life situations.

This research is conducted to evaluate and inspect mostly teachers' tendencies, perceptions and understanding of TBLT in Spain. As the reasons bump teachers execute or avoid using TBLT in the classroom, with their opinions about providing TBLT training for teachers. This research is considered as one of the essential stages in our future research project because it may affect teacher practices and smooth the way for curriculum designers in the future. The focus of this research was to give voice to Spanish teachers, allowing them to speak about their beliefs, perceptions and understanding of TBLT.

\subsection{TBLT Situation in Spain}

Spanish ELT experts and educational designers began to explore what might be the most effective method for teaching English and in 2015, the Spanish Official State Newsletter, stated to improve students' communicative competence, that learning must be based on tasks, projects, problems solving, methodologies and approaches which support this type of learning should be adopted (Boletín Oficial del Estado, 2015). This intervention paved the way for introducing task-based language teaching in Spanish schools and encouraging EFL teachers to adopt TBLT in their teaching. On the other hand, The Common European Framework of Reference (Council of Europe, 2001) gave persistent attention to task-based language teaching (TBLT) in Europe and funded the PETALL project which stands for Pan-European Task Activities for Language Learning. The project resulted from the teachers' hesitancy to use TBLT in their EFL classes and the lack of connection and collaboration among teachers. PETALL involves ten countries (Germany, Greece, Hungary, Italy, the Netherlands, Portugal, Serbia, Spain, Turkey, and the UK). The main objective is to provide teachers with good examples of good forms and methods to teach using tasks in general and using ICT and tasks and create a collaborative European atmosphere among EFL teachers and trainers for the advancement of Information and Communication Technology-based tasks. The Spanish educational authority was calling attention to promoting the learning and teaching of English in Spain. The Spanish Ministry of Education urged teachers to implement new communicative teaching methodologies in all stages and levels. One of the principles supported by the Organic Law on the Improvement of the Quality of Education (Ley Organica 8/ 2013), or Law on Education in Spain (2006), is the process of learning foreign languages throughout practice. Thus, the Spanish Official State Newsletter (Boletín Oficial del Estado, 2015) stated to improve students' communicative competence, stated that learning must be based on tasks, projects, problems solving and adopt methodologies and approaches which support this type of learning. This law helped to introduce and use TBLT in Spanish schools and require EFL teachers to adopt this approach in their teaching process. Spanish EFL teachers started diving in TBLT and Spain witnessed an increasing interest of teachers and researchers to TBLT and this appears in the participation of Spain in PETALL and the recent TBLT conference which was organized by the department of Modern Languages and Literatures and English Studies and the Language Acquisition Research Group (GRAL) at the University of Barcelona (2017). The conference's main theme was to bring together researchers and educators worldwide to talk about using tasks in different contexts ${ }^{2}$. In the Spanish context, there have been few studies focused on EFL teachers and TBLT in comparison to other countries and the focus of most of the existing research has been on the question of what constitutes a task and little practical research has been provided to support teachers (Walker, 2011).

\subsection{TBLT from Teachers' Perspectives}

Rather than focusing on TBLT and (EFL) learners, the focus of this research is on using TBLT from a teacher's perspective (Lopes \& Ruiz-Cecilia, 2017). The main research objective is to explore the understanding of TBLT amongst primary (EFL) teachers, and how this method affects their professional development in general and their performance. Extensive research has been undertaken worldwide into TBLT and its effect on the

2 http://www.tblt.org/conferences/2017/ 
teacher and learner (Jeon \& Hahn, 2006; Xiongyong \& Samuel, 2011; Jackson, 2012; Liu \& Xiong, 2016; Thi \& Tran, 2017). Xionygyong and Samuel (2011) examined English language education in secondary schools in China and gave attention to teachers' perceptions of TBLT and its impact on their teaching performance. The impetus for their research was an awareness of TBLT within the Ministry of Education and a recognition of a need for it to be implemented, much as has happened in Spain. Accordingly, the Chinese educational authority required teachers to concentrate on the teaching methodology rather than the learning outcomes (MOE, 2001). The educational authority in Spain urged teachers to implement TBLT in Spanish EFL classes (Boletín Oficial del Estado, 2015), providing the impetus for the present research. Liu and Xiong (2016) investigated college EFL teachers' attitudes towards TBLT taking into consideration their knowledge and the teaching practices which may increase or decrease using TBLT in Chinese EFL contexts. Results from these studies showed while teachers have a low understanding of TBLT (Liu \& Xiong, 2016), most EFL teachers hold positive attitudes towards it but they are afraid of implementing it in their classes because of the large class sizes and low confidence to deliver a TBLT lesson (Xionygyong \& Samuel, 2011, p.298).

Jeon and Hahn (2006) explored the perceptions of TBLT held by Korean EFL teachers, finding many respondents understood the concept of TBLT, but had concerns about whether it was suitable to be used in a Korean class. The research had shown that teachers lack knowledge of TBLT methods and techniques, and the research made it clear that TBLT will not be successful in schools if the teacher, the facilitator and the manager do not understand how TBLT works and how to conduct a TBLT lesson. Consequently, it was recommended that teachers should have sufficient knowledge about planning, delivering and assessing a TBLT course. A major reason for the reluctance of teachers to employ TBLT is related to their lack of confidence and consideration should be given to overcoming potential obstacles teachers might face in a task- based classroom.

The perception a teacher has on a teaching approach or method is critical since it plays a central role in the teacher's decision about which approach or method to be adopted in their lessons. For pre-service teachers, for the focus of this present research, perception is even more critical. For the pre-service teacher everything is new, and the perceptions form during their training may inform the whole of their subsequent teaching practice (Ansari \& Shahrokhi, 2014). Richards and Rodgers (2001) have argued teaching practice evolve in response to a distinct view of language and an understandable theory of learning (p.24). Even if all teachers share the same belief about teaching and language learning, they may implement those beliefs in different ways resulting in different classroom practices.
Several aspects impact on what teachers believe, and in turn, on how these beliefs influence classroom practices (Pajares, 1992; Phipps \& Borg, 2007). Studies conducted by Johnson (1994) and Numrich (1996) suggest teachers are strongly influenced by beliefs shaped by their expectations of teaching and their knowledge about appropriate teaching methodologies. The literature review shows using TBLT is to be extended in EFL/ESL classes in general and in primary EFL classes in particular and the perceptions teachers have of this approach are crucial and may affect implementing TBLT in their classes.

\section{Research Questions}

For the purposes of this research, the following questions have been posed.

RQ1.What knowledge, beliefs and perceptions do Spanish primary EFL teachers have of TBLT?

RQ2. What are the main reasons why teachers accept or reject using TBLT in their teaching?

RQ3. What are teachers' opinions about in-service teachers TBLT training program and their suggestions for a good implication of TBLT in the Spanish context?

\section{Methods}

\subsection{Instrument}

To collect reliable data leading to informative and credible findings which fit the literature review and provide future researchers with a solid methodological research, a teacher questionnaire was placed in convenience to the sample population and the sort of the collected data method (quantitative). The teacher questionnaire aimed to explore the Spanish EFL teachers' perceptions and understanding of TBLT. The questionnaire was adapted and modified from Jeon and Hahn's (2006), It has five sections with seventeen items.

\subsection{Participants}

The researchers selected a group of 76 Spanish primary EFL in-service teachers from elementary schools employed in Granada, Malaga and Madrid (age 28-53). The group of teachers selected for this study encompassed male (16) and female (60) veteran as well as novice teachers. Most participants were teaching in Granada (64) from public and private schools. Only five participants were from Madrid and seven were from Malaga elementary schools.

\section{Findings}

\subsection{Teachers' Quantitative Questionnaire Findings}

During this phase of research, 76 teachers filled out the 
questionnaire. The aim was to explore in-service teachers' understanding, perceptions and beliefs on TBLT, the reasons teachers use or avoid TBLT and their views on providing TBLT training for teachers. The questionnaire was divided into three sections.

\subsubsection{Teachers' Knowledge of TBLT}

RQ1: What knowledge, beliefs and perceptions do Spanish primary EFL teachers have of TBLT?

Table 1 shows cases that for 1-7 most participants agreed with the items, and there was no strong disagreement. For items 1 to 3 which tested the participants' knowledge of some key concepts of task, most participants agreed a task is a communicative goal directed (73.6\%), involves a primary focus on meaning $(77.6 \%)$ and has a clearly defined outcome (71\%). In response to item $4,(60.5 \%)$ of the participants agreed that a task is an activity in which the target language is used by the teacher. For item 5, related to learners' position in TBLT, more than half of the participants (76.3\%) agreed that TBLT is learner-centered approach. The findings of items 6 and 7, related to TBLT structure, showed the participants $(64.4 \%)$ to some extent are aware that TBLT is consistent with the principles of communicative language teaching and most of them (69.7\%) recognize TBLT includes three stages.

\subsubsection{Teachers' Views on Implementing TBLT}

RQ2: What are the main reasons why teachers accept or reject using TBLT in their teaching?

In this part of research, table 2 shows that respondents' answers vary between agree and strongly agree with few answers between disagree and neutral and no strong disagreement with any items in this section. In response to item 8 , about half of the participants (68.4\%) strongly agree to implement TBLT in the classroom and only $(2.6 \%)$ either disagree or neutral. In contrast, in item 9 , most of the participants $(67.1 \%)$ neither agree, strongly agree, disagree nor strongly disagree, they are neutral. For item 10 , the provided results are balanced between agree $(50 \%)$ and strongly agree $(46 \%)$ that TBLT takes into account learners' needs and interests and only (3.9\%) who are neutral with neither strong disagreement nor disagreement. Item 11, less than half of the respondents (44.7\%) agree and strongly agree and showed positive responses regarding TBLT pursuing the development of integrated skills in the classroom whereas only $(10.5 \%)$ showed some negative responses concerning this statement. The findings for item 12 reveal that the majority of the respondents (72.3\%) strongly agree and believe that TBLT may encumber teachers at the psychological level, (13.1\%) agree and (14.4\%) neither agree or disagree. The findings of items 13 and 14, which explore teachers' actions inside and outside a TBLT class, affirm that most of the teachers $(64.4 \%)$ are aware to the load of time required to prepare a TBLT lesson in comparison to other approaches. On the other hand, for item 14, even though some respondents (38.1\%) agree but the larger part $(56.5 \%)$ of the respondents show their uncertainty of TBLT as a proper approach for classroom management. In the end, item 15 gives more balanced results because 42 participants $(27.6 \%)$ either strongly agree or agree that materials in textbooks are meaningful and purposeful based on real-world context and $(28.9 \%)$ of them disagree whereas $(15.7 \%)$ are neutral related to this statement.

Table 1. Teachers' knowledge of TBLT

\begin{tabular}{|l|l|l|l|l|l|l|}
\hline & Statement & Strongly Disagree & Disagree & Neutral & Agree & Strongly Agree \\
\hline 1 & A task is a communicative goal directed & $0 \%$ & $0 \%$ & $7.89 \%$ & $\mathbf{7 3 . 6 8 \%}$ & $18.42 \%$ \\
\hline 2 & A task involves a primary focus on meaning & $0 \%$ & $0 \%$ & $6.57 \%$ & $\mathbf{7 7 . 6 3 \%}$ & $25 \%$ \\
\hline 3 & A task has a clearly defined outcome & $0 \%$ & $6.57 \%$ & $5.26 \%$ & $\mathbf{7 1 \%}$ & $17.10 \%$ \\
\hline 4 & $\begin{array}{l}\text { A task is an activity in which the target language } \\
\text { issued by the learner }\end{array}$ & $0 \%$ & $14.47 \%$ & $6.57 \%$ & $\mathbf{6 0 . 5 2 \%}$ & $18.42 \%$ \\
\hline 5 & $\begin{array}{l}\text { TBLT supports learner-centeredness rather than } \\
\text { teacher-centeredness }\end{array}$ & $0 \%$ & $0 \%$ & 14 & $\mathbf{7 6 . 3 1 \%}$ & $5.26 \%$ \\
\hline 6 & $\begin{array}{l}\text { TBLT is a sub-branch of communicative language } \\
\text { teaching includes three stages : pre-task, }\end{array}$ & $0 \%$ & $3.94 \%$ & $9.21 \%$ & $\mathbf{6 4 . 4 7 \%}$ & $21.05 \%$ \\
\hline 7 & $\begin{array}{l}\text { TBLT int-imp } \\
\text { task-implementation, and post-task }\end{array}$ & $0 \%$ & $7.89 \%$ & $\mathbf{6 9 . 7 3 \%}$ & $23.68 \%$ \\
\hline
\end{tabular}


Table 2. Teachers' views on implementing TBLT

\begin{tabular}{|l|l|l|l|l|l|l|}
\hline & Statement & Strongly Disagree & Disagree & Neutral & Agree & Strongly Agree \\
\hline 8 & $\begin{array}{l}\text { I have interest in implementing TBLT in the } \\
\text { classroom }\end{array}$ & $0 \%$ & $\mathbf{2 . 6 3} \%$ & $\mathbf{2 . 6 3 \%}$ & $26.31 \%$ & $\mathbf{6 8 . 4 2 \%}$ \\
\hline 9 & $\begin{array}{l}\text { TBLT provides a relaxed atmosphere to promote the } \\
\text { target language use }\end{array}$ & $0 \%$ & $\mathbf{6 7 . 1 0 \%}$ & $3.94 \%$ & $23.68 \%$ \\
\hline 10 & $\begin{array}{l}\text { TBLT takes into account learners needs and } \\
\text { interests }\end{array}$ & $0 \%$ & $0 \%$ & $\mathbf{3 . 9 4 \%}$ & $\mathbf{5 0 \%}$ & $\mathbf{4 6 . 0 5 \%}$ \\
\hline 11 & $\begin{array}{l}\text { TBLT pursues the development of integrated skills in } \\
\text { the classroom }\end{array}$ & $0 \%$ & $\mathbf{1 0 . 5 2 \%}$ & $0 \%$ & $\mathbf{4 4 . 7 3 \%}$ & $\mathbf{4 4 . 7 3 \%}$ \\
\hline 12 & $\begin{array}{l}\text { TBLT gives much psychological burden to the } \\
\text { teacher as a facilitator }\end{array}$ & $0 \%$ & $\mathbf{1 4 . 4 7 \%}$ & $\mathbf{1 3 . 1 5 \%}$ & $\mathbf{7 2 . 3 6 \%}$ \\
\hline 13 & $\begin{array}{l}\text { TBLT requires more preparation time compared to } \\
\text { other approaches }\end{array}$ & $0 \%$ & $5.26 \%$ & $6.57 \%$ & $23.68 \%$ & $\mathbf{6 4 . 4 7 \%}$ \\
\hline 14 & $\begin{array}{l}\text { TBLT is proper for controlling classroom } \\
\text { arrangements }\end{array}$ & $0 \%$ & $2.63 \%$ & $\mathbf{5 6 . 5 7 \%}$ & $\mathbf{3 8 . 1 5 \%}$ & $2.63 \%$ \\
\hline 15 & $\begin{array}{l}\text { TBLT materials in textbooks are meaningful and } \\
\text { purposeful based on real-world context }\end{array}$ & $0 \%$ & $\mathbf{2 8 . 9 4 \%}$ & $\mathbf{1 5 . 7 8 \%}$ & $\mathbf{2 7 . 6 3 \%}$ & $\mathbf{2 7 . 6 3 \%}$ \\
\hline
\end{tabular}

\subsubsection{Teachers' Reasons to Implement or Avoid TBLT}

\subsubsection{Teachers' Reasons to use TBLT}

According to table 3, most of the teachers' reasons to implement TBLT in their classroom are because of its advantage to encourage teachers to be creative in their classroom (94.7\%), promote students' learning communicative skills (97.3\%), its appropriateness to small group $(92.1 \%)$, in addition to its nature to encourage learners' intrinsic motivation $(81.5 \%)$. In contrast, few respondents believe that TBLT creates a collaborative learning environment (28.9\%). Overall results imply that teachers agree that TBLT is relevant for teachers as well as students in some cases but not all.

Table 3. Teachers' reasons to use TBLT

\begin{tabular}{|c|l|c|}
\hline & Reasons & Results \\
\hline a & $\begin{array}{l}\text { TBLT encourages teachers to be creative in their } \\
\text { lessons. }\end{array}$ & $94.73 \%$ \\
\hline b & $\begin{array}{l}\text { TBLT promotes students' learning communicative } \\
\text { skills. }\end{array}$ & $97.36 \%$ \\
\hline c & TBLT encourages learners' intrinsic motivation. & $81.57 \%$ \\
\hline d & $\begin{array}{l}\text { TBLT creates a collaborative learning } \\
\text { environment. }\end{array}$ & $28.94 \%$ \\
\hline E & TBLT is appropriate for small group work. & $92.10 \%$ \\
\hline
\end{tabular}

\subsubsection{Teachers' Reasons to Avoid TBLT Implementation}

Table 4 lists the teachers' responses about their own reasons for avoiding the use of TBLT in their classes. In response to reason (f), only (7.8\%) among a total of 76 respondents avoid the use of TBLT because it is a new brand of teaching for teachers. However, data analysis demonstrated that the majority of the respondents choose the reasons that are related to their teaching performance $(\mathrm{g}, \mathrm{h}, \mathrm{i})$. For instance, the majority of the respondents claimed that they refrain from applying TBLT because they are not used to teach English using this approach $(97.3 \%)$, they have very little knowledge of task-based instruction (98.6\%), and their inability in assessing learners' task-based performance. For reasons ( $\mathrm{j}$ and $\mathrm{k}$ ), few respondents $(15.7 \%)$ showed their abstinence from using TBLT by reason of the inappropriate materials in textbooks, and only (11.8\%) avoid TBLT owing to the large class size where it is impossible to implement an approach like TBLT.

Table 4. Teachers' reasons to avoid TBLT implementation.

\begin{tabular}{|c|l|l|}
\hline & Reasons & Results \\
\hline $\mathrm{f}$ & It is a new brand of teaching. & $7.89 \%$ \\
\hline $\mathrm{g}$ & I am not used to teach English using TBLT. & $97.36 \%$ \\
\hline $\mathrm{h}$ & $\begin{array}{l}\text { I have very little knowledge of task-based } \\
\text { instruction. }\end{array}$ & $98.68 \%$ \\
\hline $\mathrm{i}$ & $\begin{array}{l}\text { I have difficulty in assessing learners' task-based } \\
\text { performance. }\end{array}$ & $94.73 \%$ \\
\hline $\mathrm{j}$ & $\begin{array}{l}\text { Materials in textbooks are not proper for using } \\
\text { TBLT. }\end{array}$ & $15.78 \%$ \\
\hline $\mathrm{k}$ & $\begin{array}{l}\text { Large class size is an obstacle to use task-based } \\
\text { methods. }\end{array}$ & $11.84 \%$ \\
\hline
\end{tabular}

\subsubsection{Teacher's Teaching Training Experience}

This part is related to the third research question that states:

RQ3: Did you complete a teacher education or training program before or after starting teaching?

This section of the questionnaire contained a yes/no question which was related to this research question. If the respondents answered 'Yes', they had to fill in the table explaining the teaching training they had, but if they answered 'No', they move to the last open-ended questions without filling in table 5.

This question includes three items revolving around teachers' teaching training experience. The found data showed most participants $(86.8 \%)$ had almost the same teaching training experience and only $(13.5 \%)$ of them did not have a training experience or did not want to mention it for personal reasons maybe. In this question, for the participants who answered 'Yes', they had to explain the training they had by saying the period, the date and the training objectives. According to their answers, it 
appeared that the training they had were nearly the same and flow into the same training objective and content. As portrayed in table 5, the majority of the participants $(84.8 \%)$ had the training at schools mainly as assistant teachers, $(10.6 \%)$ participants had the training at the university which means before they start teaching and the remaining $(4.5 \%)$ had an online training experience. Item $\mathrm{b}$, gives more balanced results because $(46.9 \%)$ of the participants had training for three months or less than three months whereas, none of the participants had a teaching training more than three months. Most of the training period was generally ranked between four weeks to six weeks. For item C, the participants declared that they were disappointed of the training objectives they had attended and they were mainly about either teaching English activities or games $(87.8 \%),(18.1 \%)$ attended training about classroom practices and only (12.1\%) had EFL/ESL training.

Table 5. Teachers' teaching training experience.

\begin{tabular}{|c|c|c|c|c|}
\hline & & Total & $\mathrm{N}$ & $\%$ \\
\hline 16 & Teachers' teaching training experience & & 66 & 86.84 \\
\hline \multirow[t]{4}{*}{ A } & Where & & & \\
\hline & & University & 7 & 10.60 \\
\hline & & School (assistant teacher) & 56 & 84.84 \\
\hline & & Online & 3 & 4.5 \\
\hline \multirow[t]{4}{*}{ B } & How long & & & \\
\hline & & Three months & 31 & 46.96 \\
\hline & & More than three months & 0 & 0 \\
\hline & & Less than three months & 31 & 46.96 \\
\hline \multirow[t]{4}{*}{$\mathrm{C}$} & Training content and topics & & & \\
\hline & & Teaching English activities and games & 58 & 87.87 \\
\hline & & Classroom practices & 12 & 18.18 \\
\hline & & EFL/ESL training & 8 & 12.12 \\
\hline
\end{tabular}

Table 6. Analysis of Themes from Open Question (Question Number 17).

\begin{tabular}{|l|l|}
\hline Theme & Excerpts \\
\hline \multirow{4}{*}{ TBLT training quality } & $\begin{array}{l}\text { TBLT training should be hold in real contexts (authentic schools). } \\
\text { Provide training based on teachers' needs. } \\
\text { Create very specific training in terms of content (objectives). } \\
\text { Spanish EFL teachers need more instruction on the training coming from abroad. } \\
\text { The three stages of TBLT should be deeply explained during the training. } \\
\text { Give more importance to teachers' practices and feedback in a TBLT training. } \\
\text { Help teachers create enjoyable, well planned task-based lessons and TBLT assessment. } \\
\text { Present the advantages and disadvantages of TBLT and train teachers how to overcome the tasks' } \\
\text { obstacles. }\end{array}$ \\
\hline $\begin{array}{l}\text { Teaching curriculum and } \\
\text { textbook in favor of TBLT } \\
\text { principles }\end{array}$ & $\begin{array}{l}\text { Spanish EFL textbooks should be reviewed. } \\
\text { Provide prepared TBLT lessons based on the school textbook to teachers. } \\
\text { Adjust textbooks to the TBLT principles. } \\
\text { Present textbooks are difficult for novice teachers to use and apply TBLT at the same time. }\end{array}$ \\
\hline $\begin{array}{l}\text { Teachers involvement in } \\
\text { TBLT decisions }\end{array}$ & $\begin{array}{l}\text { Make teachers aware of the TBLT principles. } \\
\text { Create a cooperative atmosphere between teachers and educational decision makers. } \\
\text { Take the teachers' opinions and views in all matters. } \\
\text { Give teachers a large space inside the school in teaching and learning decisions. } \\
\text { Integrate teachers in the creation and production of teaching materials. } \\
\text { Consult and involve teachers in the creation of teaching training. }\end{array}$ \\
\hline $\begin{array}{l}\text { Facilitate the integration of TBLT. } \\
\text { Help raise awareness among teachers and at schools. } \\
\text { Financial and educational support to install a new approach like TBLT. } \\
\text { Creation of a national online platform for teachers. } \\
\text { Create a supportive environment for teachers by the issue of new resolutions that are in the favor of the } \\
\text { teachers'and learners' favor. }\end{array}$ \\
\hline
\end{tabular}




\subsection{Qualitative Results}

\subsubsection{Special Recommendations for TBLT Implication in Spain}

To get additional facts about successful implication of TBLT in the Spanish context, an open question (Q17) was investigated. This question paved the way for teachers to share their opinions about the idea of providing TBLT training for Spanish language teachers and what special considerations they think are important to ease the TBLT implementation in Spain. As the question is open, not all teachers provided answers. Out of the 76 teachers who filled in the whole questionnaire, 63 teachers responded to the final question. The answers were coded for thematic analysis (Gilham, 2005) and counted in an Excel document. Coming out from this, four main themes were introduced: a) problems related to TBLT training quality; b) the need of adequate teaching curriculum and textbooks to TBLT; c) the need to integrate and involve teachers in TBLT decisions; d) issues related to the unsupportive educational and institutional environment in Spain. The former themes are more illustrated in Table 6.

Teachers claim that providing training for teachers can be the master key to create an existence for TBLT among the Spanish teachers. Many teachers suggest that before providing a new learning style for students, teachers should be first exposed to this teaching style, well informed and trained. Thus, teachers' comments were mainly about the quality of TBLT training and objectives. One teacher suggested that TBLT training can only succeed if they are organized in real contexts like in authentic schools, though another respondent recommended the importance of narrowing the TBLT training objectives, explaining that instead of making a global training, each university or school is able to make very specific training in terms of content and trainees' needs. In the same vein, three respondents added that teachers need clear instructions and training imported from abroad and they should be adjusted to the teachers' educational and cultural background. Another teacher focused on the three phases of TBLT lesson and suggested that these three phases should be highly explained to teachers to learn how to manage lesson time to these stages. In contrast, another respondent claimed that teachers are not obliged to rely and obey the TBLT lesson phases due to time limits. Finally, two respondents recommend that TBLT training programs should familiarize teachers with the advantages and disadvantages of TBLT and teachers should be given the opportunity to be trained and informed in streams relating to the task-based lesson planning, presentation and evaluation.

The second theme relates to the Spanish EFL teaching curriculum and textbook appropriateness to TBLT. Most of the teachers believe in the possibility of TBLT application in the Spanish context and their comments are mainly about changes at the level of teaching curriculum and textbook objectives that must be in favor of TBLT principles. The majority of respondents' comments were on the urgent need to adjust the Spanish EFL textbooks to TBLT standards. Two respondents suggested that schools should provide their teachers with prepared TBLT lessons based on the school textbooks in order to ease the TBLT implementation. Adding to that, another respondent declared that the content of school textbooks is not in line with the teaching goals designed by teachers. One of the respondents is a novice teacher discussing this issue which he faced and exhausted him a lot during his first year of teaching and suggested that the size of content must be reviewed in the Spanish EFL textbooks. One suggestion was that teaching curriculum and textbook content must first reach the teachers' requirements and be highly accepted by teachers more than students.

The third theme reaches the Spanish EFL teachers' integration and involvement in the TBLT decisions. Many comments discussed the importance of making the schools, materials developers and TBLT decision makers aware of the need of incorporating teachers in any teaching decision. Some voiced that a collaborative atmosphere should be created between teachers, teacher trainers and material designers in order to come out with a balanced teaching system and highly informed teachers. Some respondents focus on the necessity to help teachers construct their personal teaching theory in line with the external teaching influences in order to facilitate the TBLT use. Two respondents discussed that due to the learner-centered nature of TBLT, much attention should be given to the teacher in order help them realize and differentiate their roles in a TBLT lesson, for example, by providing special training explaining the different roles of the teacher in a learner-centered approach like TBLT, or by helping teachers to be materials developers like adapting or developing TBLT teaching materials that are suitable for them and for their students. One teacher suggested that due to the low confidence of teachers in using TBLT, much consideration should be given to overwhelm these restrictions when teaching.

The fourth theme relates to the role of the educational and institutional support in Spain for implementing TBLT. In contrast to the first three themes, which contain suggestions that any teacher can practically achieve. The present theme involves an issue far from the language teachers' hands. The majority of the respondents suggested that the language learning and teaching process in Spain should be thoroughly reviewed before the introduction of TBLT in the Spanish EFL classes. One respondent pointed to those decision makers in charge of the educational system that have to turn their attention to better boost TBLT adoption in the Spanish context. Two teachers talked about the financial and education support of the government to implement TBLT or any new teaching reform in Spain. Additionally, many teachers 
talked about the creation of a national online platform to exchange ideas on teaching using TBLT in the Spanish context. As it is stated by two teachers, Spanish EFL teachers are sinking in unsupportive teaching environment; therefore, the concerned parties should intervene in this matter and give space to teachers to express their concerns regarding the teaching methodologies in particular.

\section{Discussion}

According to the first research question, the results gathered from items 1 to 7 show the fact that teachers have a good handle of the linguistic characteristics of tasks, which favor tasks implication in Spanish EFL/ESL classrooms. Despite the different teaching styles, teachers have considerable knowledge of the distinguished features of TBLT. Thus, teachers' awareness and knowing of TBLT refer to educational reforms imposed by the Spanish Ministry of education by giving value to the implication of TBLT in Spanish language classrooms.

Concerning results to item 8 through 15 , which examined teachers' views and attitudes on TBLT implementation, revealed that the Spanish EFL teachers have a tendency towards the implementation of TBLT in English language classrooms. In contrast, teachers are still not certain of their ability to use this approach in their classes and they need more progress and adaptation of TBLT to their teaching. The teachers showed their awareness of the negative side of TBLT and the obstacles they may face if they decide to use it. These findings affirm that despite the Spanish teachers' knowledge and understanding of TBLT, they are still hesitant to practice TBLT principles in their classes. These results are consistent with the results of Ansari and Shahrokhi's (2014) study, in which they reached the same concept that though most of the Iranian EFL teachers understand what tasks are but they are reluctant to use TBLT in their classes.

Before talking about the three principle of TBLT that encompass task, teachers' roles and classroom management, it is customary to Spanish teachers that are used to working in a way that allows the maintenance of the internal system of the classroom. That's why Spanish teachers are called to create a more encouraging, pleasant and convenient learning atmosphere in which learners actively engage and be into the learning process.

In response to the second research question, results bring out into open the reasons why teachers choose or avoid implementing TBLT. The majority of teachers' favor TBLT implementation by virtue to its creative and collaborative nature, or due to its appropriateness for small group work or its motivational advantage. Some other teachers choose to use this method as long as it enhances learners' communicative skills and believe that this approach descends from learning theories rather than the linguistic features (Johnson, 2004). On the other hand, there are some challenges that teachers face and prevent them from using task-based approach. Given reason to that teachers are not accustomed to teaching using this approach, their little knowledge of task-based instructions in addition to the difficulty in assessing learners' task-based performance are the primary reasons teachers avert this approach. Teachers believe that they do not have the required experience and mastery to apply TBLT and are used to the traditional teaching methods that depend on teacher-centered lessons. This rejection of TBLT reflects their lack of confidence and knowledge of task performance. Therefore, teachers with low confidence and little knowledge of TBLT, cannot create a supporting learning atmosphere, inspire learners' confidence, and help them successfully complete task-based activities. These findings are in line with those of (Jeon \& Hahn, 2006; Thi \&Tran, 2017; Ansari \& Shahrokhi, 2014) who claimed in their studies that teachers reject TBLT adoption because of their low self-confidence. Thus, these issues can be solved by exposing teachers to more TBLT training and techniques in order to help teachers construct positive perceptions of TBLT implication in the Spanish EFL classrooms. Thus, the more teachers' confidence is high the more learners' active participation in a task-based lesson increases and teaching starts to shift toward more learner-centered teaching (Burdett, 2003; Harris, 2016).

For the other two obstacles, only few teachers declared that they cannot use TBLT due to the unsuitableness of the textbook materials and the large-sized class. These findings make us realize that the current EFL textbooks in Spain's primary schools are characterized by their task-based syllabus (Boletín Oficial del Estado, 2015). TBLT gained popularity in Spain, much light must be shed on the formation of the Spanish EFL teachers and raise their professional ability in using TBLT, rather than focusing on the teaching materials and context in EFL Spanish classes. This preliminary common sense is in line with Zare (2007) who suggested teachers can be the master key to successfully insert TBLT in any educational system.

As the last point, findings to the third research question revealed that Spanish teachers didn't have the opportunity to attend TBLT training. Based on their responses it is illustrated the most training done were at the university (before starting teaching) and no more than three months and were general training. This demonstrates the shortage of teachers' support at the training. This explains teachers' belief in their role to introduce TBLT practices in the Spanish EFL classes. This explains whay teachers believe that certain instructional approaches affect the adoption of any approach. This research clarified all respondents who agree teachers who use TBLT in the classroom should get a TBLT training. As it is stated by the (Boletín Oficial del Estado, 2015), Spanish teachers are required to teach English using tasks, teachers' strength to adapt and 
improved teaching material should be highlighted. From one side, teachers in Spain are frequently requested to use a textbook administered by the school and on the other hand are required to teach using tasks. Thus, teachers need much care and support in adapting, evaluating and producing materials, to guarantee the consistency of the materials with the learners and go along with the teaching context. These beliefs lead teachers to provide suggestions about the nature and quality of the training objectives they need most. It is remarked teachers believe in the possibility of TBLT application in the Spanish context in case training developers, curriculum and material designers help teachers construct their personal policy when facing educational changes, provide training that raise teachers' confidence in using TBLT, plan training with specific and direct objectives and last, create a collaborative atmosphere or a national online platform to share with teachers ideas on task implementation in the Spanish context.

\section{Conclusions}

This study investigated teachers' perceptions and understanding of TBLT and its application and integration in the Spanish context. The results of the study are summarized in terms of three research questions, and some initial prudence on the Spanish EFL teachers conception in this research context affirms that the majority of the respondents have a great knowledge and understanding of TBLT principles and they are aware of the ability of TBLT in enhancing learners' communicative skills. For the first research question, and despite the high understanding of TBLT, tendency of the participants towards the integration of tasks in the Spanish EFL classes and their positive reaction to the Spanish educational reforms, Spanish primary EFL teachers are still hesitant in either using or avoiding TBLT in their classes. This reluctance to adopt TBLT mainly resulted from the disciplinary problems of TBLT principles which teachers may face in class. It was found teachers are aware of the advantages and disadvantages of TBLT. Results of question two revealed every teacher has his or her own reason to approve or disapprove using this approach when teaching. The majority favor using TBLT because of its creative and communicative nature, appropriateness for small group work and its motivational advantage on learners, whereas other teachers avoid this approach because of their personal weakness as professors using this approach and their ignorance and lack of instructional resources. Research question three differs from the first two research questions which explored teachers' teaching training experience and their attitudes towards TBLT training for Spanish EFL teachers. Results indicated teachers have a poor training experience in general and have no practical experience (training) of applying TBLT in class; as a result, most of the teachers agree to need TBLT training for teachers at all levels and stages. To reach this, TBLT could successfully be applied if essential adjustments are considered. Training programs which are planned to train and improve teachers teaching methodologies knowledge should clarify both the positive and negative sides of TBLT as a communicative teaching method. Second, teaching training programs should adopt effective objectives and be organized in authentic environments. As teachers always play a key role in the success or failure of any teaching method, TBLT training should train teachers how to adapt and develop teaching materials and how they can be materials developers for a TBLT lesson. Throughout this study, it is highlighted that Spanish EFL teachers' main problem in adopting TBLT or any other teaching method resulted from their lack of confidence, low professional skills and unpreparedness in using a teaching approach like TBLT in their classes. Wherefore, much consideration should be done to overwhelm the barriers that teachers may encounter in real task-based classroom. In addition to the hints made by the Spanish Ministry of education on the need to teach using TBLT, educational centers and teachers' organizations must contribute and work on the creation of a national online platform for teachers to exchange ideas on teaching using TBLT in the Spanish context. Simultaneously, teachers are recommended to try alternative solutions for classroom practices like trying different types of tasks (two-way information gap, comparing, problem-solving, ordering and sorting...etc) in addition to class order (group/pair work). Training teachers to adopt TBLT into their teaching routines is fundamental. If teachers are not well formed and not competent in using TBLT properly, any reform in language teaching will not be attainable.

\section{REFERENCES}

[1] K. Ansari, M. Shahrokhi. Iranian teachers' conceptions of task-based language teaching: a case study of 40 English teachers in Gachsaran, International Journal of Language Learning and Applied Linguistics World, Vol.7, NO.3, 122-137, 2014.

[2] Boletín Oficial del Estado (2015). Ministerio de Educación, Cultura y Deporte (BOE) num.25, de 29 de enero de 2015. Referencia: BOE-A-2015-738.

[3] M.P. Breen. Learner contributions to task design. In C.N. Candlin \& D. Murphy (Eds.), Lancaster Practical Papers in English Language Education, Language learning tasks 7, 23-46. Englewood Cliffs, NJ: Prentice Hall, 1987.

[4] J. Burdett. Making groups work: University students' perceptions. International Education Journal, Vol.4, NO.3, 177-191, 2003.

[5] M. Bygate. Effects of task repetition on the structure and control of oral language. In M. Bygate, P. Skehan, \& M. 
Swain, (Eds.), Researching pedagogic tasks: Second language learning, teaching and testing Harlow, UK: Longman, 2001.

[6] C. Candlin, D. Murphy. Language Learning Tasks (Eds). Englewood Cliffs, N.J.: Prentice Hall International, 1987.

[7] C. N. Candlin. Towards Task-based Learning. In C. Candlin, \& D. Murphy (Eds.), Lancaster practical papers in English language education, Volume 7: Language Learning Tasks (pp. 5-22). Englewood Cliffs, NJ: Prentice Hall, 1987.

[8] Council of Europe. (2001). Common European framework of reference for languages: Learning, teaching, assessment. Cambridge, U.K.: Press Syndicate of the University of Cambridge.

[9] G. Crookes. Task classification: a cross-disciplinary review. Technical Report no. 4, Center for Second Language Classroom Research, Social Science Research Institute, University of Hawai'I, 1986.

[10] R. Ellis. Task-based language learning and teaching. Oxford: Oxford University Press, 2003.

[11] B. Gilham. Research Interviewing: The Range of Techniques (1st ed.). Berkshire: Open University Press, 2005.

[12] J. Harris. Teachers' beliefs about task-based language teaching in Japan. The Journal of Asia TEFL, Vol. 13, NO.2, 102-116, 2016.

[13] M. Hişmanoğlu, S. Hişmanoğlu. Task-based language teaching: What every EFL teacher should do. Procedia-Social and Behavioral Sciences, Vol. 15, 46-52, 2011.

[14] D. O. Jackson. Task-based language teacher education in an undergraduate program in Japan. In A, Shehadeh \& C.A. Coombe (Eds.), Task-based language teaching in foreign language contexts: Research and implementation (pp.267-285). Amsterdam/Philadelphia: John Benjamins, 2012.

[15] I. Jeon, J. Hahn. Exploring EFL teachers' perceptions of task-based language teaching: a case study of Korean secondary school classroom practice. Asian EFL Journal, Vol.8, 1-27, 2006.

[16] K. Johnson. From communicative activity to task: A short but significant journey. The Journal of Asia TEFL, Vol.1, NO.1, 185-195, 2004.

[17] K.E. Johnson. The emerging beliefs and instructional practices of pre-service English as a second language teachers. Teaching and Teacher Education, Vol.10, NO. 4, 439-452, 1994.

[18] Ley Organica 8/2013, de 9 de diciembre, para la Mejora de la Calidad Educativa (BOE, N 295 10-12-2013).

[19] Y. Liu, T. Xiong. Situated task-based language teaching in Chinese colleges: Teacher education. Journal of English Language Teaching, Vol.9, NO.5, 22-32, 2016.

[20] M.H. Long,. A Role for instruction in second language acquisition: Task-based language teaching. In Hyltenstam, K. and M. Pienemann (eds.), Modelling and Assessing Second Language Acquisition. Clevedon: Multilingual
Matters, 77-99, 1985.

[21] A. M. B. Lopes, R. Ruiz-Cecilia. Designing technology-mediated tasks for language learning: A methodological framework. Acetize University Journal of Education, Vol. 32, NO.), 265-279, 2017.

[22] MOE (Ministry of Education). (2001). National English curriculum standards for nine-year compulsory education and senior high school education. Beijing: People's Education Press.

[23] C. Numrich. On becoming a language teacher: Insights from diary studies. TESOL Quarterly, Vol. 30, No.1, 131-53, 1996.

[24] D. Nunan. Designing tasks for the communicative classroom. Cambridge: Cambridge University Press, 1989.

[25] M.F. Pajares. Teachers' beliefs and educational research: cleaning up a messy construct. Review of Educational Research, Vol. 62, NO.3, 307-32, 1992.

[26] S. Phipps, S. Borg. Exploring the relationship between teachers' beliefs and their classroom practice. The Teacher Trainer, Vol.21, NO.3, 17-19, 2007.

[27] N. S. Prabhu. Second language pedagogy. Oxford, UK. Oxford University Press, 1987.

[28] R. Ruiz-Cecilia. Reframing foreign language learning and teaching: ICT-based tasks. In Davide Capperucci Innovative European Approaches for In-service and Pre-service English Language Teachers in Primary Education (pp. 135-163). Pisa: Edizioni ETS, 2017.

[29] J. Richards, T. Rodgers. Approaches and methods in language teaching. Cambridge: Cambridge University Press, 2001.

[30] P. Skehan. Task-based instruction. Annual Review of Applied Linguistics, Vol.18, 268-286, 1996.

[31] P. Skehan. A cognitive approach to language learning. Oxford: Oxford University Press, 1998.

[32] Teaching and Learning International Survey. Teaching and learning international survey: User's guide to 2013 U.S, 2013.

[33] A.N. Thi, N. S. Tran. In-service teachers' reaction to a training program of Task-based language teaching: A case study of English language teachers in Vietnam. IOSR Journal of Research \& Method in Education, Vol. 7, N.3, 53-68, 2017.

[34] M. Walker. Task-based language teaching: a classroom framework, Research into practice conference, Qatar, 2011.

[35] J. Willis. A framework for task-based learning. London: Longman, 1996.

[36] C. Xiongyong, M. Samuel. Perceptions and implementation of task-based language teaching among secondary school EFL teachers in China. International Journal of Business and Social Science, Vol. 2, NO.24, 292-302, 2011.

[37] G. Zare. The Attitudes of the Iranian EFL Learners and Teachers towards Task-based Language Teaching. Unpublished MA thesis, Shiraz University, Shiraz, 2007. 